\title{
Daniel J. Siegel, Mind: A Journey to the Heart of Being Human, W. W. Norton \& Company, New York-London 2017, ss. 400
}

\begin{abstract}
Daniel J. Siegel jest profesorem psychiatrii na Uniwersytecie Kalifornijskim w Los Angeles, doktorem Uniwersytetu Harvarda oraz współzałożycielem Mindful Awareness Research Center i dyrektorem wykonawczym Mindsight Institute - jednostek organizacyjnych prowadzących badania nad praktykami uważności (m.in. mindfulness) oraz propagujących i edukujących o sposobach łączenia odkryć naukowych z praktycznymi zastosowaniami $\mathrm{w}$ postaci doskonalenia zdolności do psychowzroczności ${ }^{1} \mathrm{~W}$ celu osiągania dobrostanu psychofizycznego. Siegel jest autorem kilkunastu książek, w tym The Developing Mind: How Relationships and the Brain Interact to Shape Who We Are (The Guilford Press, New York-London 2012), w której dokładnie przedstawia założenia dotyczące opracowywanej przez niego teorii Neurobiologii Interpersonalnej (IPNB - Interpersonal Neurobiology), w tym koncepcję umysłu, gdzie jeden z jego aspektów jest definiowany jako ucieleśniony i relacyjny proces regulujący przepływ informacji i energii. Jednym z celów tej teorii było uzyskanie takiej zoperacjonalizowanej definicji umysłu, która byłaby akceptowalna w kontekście interdyscyplinarnym, czyli z uwzględnieniem jak największej liczby dziedzin zajmujących się badaniem umysłu bądź odnoszącym się do niego na różne sposoby - od filozofii, religii, sztuki, psychologii i socjologii po neurobiologię, antropologię czy psychiatrię, a nawet fizykę i teorię systemów złożonych.
\end{abstract}

\footnotetext{
${ }^{1}$ Mindsight - termin ukuty przez Siegela, oznaczający zdolność do postrzegania swojego umysłu oraz umysłów innych ludzi; więcej informacji na stronie domowej Siegela: http://www. drdansiegel.com/about/mindsight/ (dostęp: 4.03.2017).
} 
Recenzowana przeze mnie najnowsza książka Siegela Mind: A Journey to the Heart of Being Human stanowi po części autobiograficzny zapis rozwijanej od ponad dwudziestu lat wyżej wspomnianej koncepcji umysłu (ponadto z nawiązaniami do wczesnych rozważań trwających od lat siedemdziesiątych) oraz związanej z nim reguły organizującej jego działanie, czyli integracji, oznaczającej łączenie ze sobą dobrze zróżnicowanych części. Według Siegela jakość funkcjonowania umysłu - nasz dobrostan psychofizyczny - zależy od jakości integracji powstającej naturalnie w wyniku usuwania takich dezintegrujących zjawisk jak chaos i/lub sztywność, przeszkadzających w jej emergentnym formowaniu się.

Książka została podzielona na dziesięć rozdziałów, w których autor przeplata przedstawianie bardzo złożonych idei z wątkami autobiograficznymi podzielonymi na pięcioletnie okresy (od 1975 roku do dziś). W pierwszym rozdziale Siegel wprowadza do dyskusji nad poglądami na temat umysłu, przywołując najbardziej powszechny z nich, obowiązujący we współczesnej nauce, który można sprowadzić do słów, że „umysł jest tym, co robi mózg”. Autor konfrontuje to stanowisko, rozważając relacyjną naturę umysłu, będącego zawsze w relacji do czegoś, na przykład do swoich własnych stanów wewnętrznych, jak i w relacji do innych umysłów i sfery umysłowej (społeczeństwo, kultura), które pojedynczy umysł tworzy i jest poprzez nie tworzony. Kolejne tytuły rozdziałów mają postać pytań, na które Siegel udziela odpowiedzi, przybliżając dzięki temu różne aspekty tego, czym jest i jak działa umysł. Drugi rozdział What Is the Mind? omawia pracę autora w latach dziewięćdziesiątych $\mathrm{w}$ interdyscyplinarnym zespole nad definicją umysłu oraz reguły działania systemów złożonych, które mają odzwierciedlenie w takich własnościach działania umysłu, jak regulacja przepływu energii i informacji, samoorganizacja, emergencja oraz specyficzne związki przyczynowe w tego typu systemach. Rozdział trzeci How Does the Mind Work in Ease and Dis-Ease? rozwija wątek systemów złożonych poprzez wprowadzenie pojęcia integracji i jej związków ze zdrowiem psychicznym. Rozdział czwarty Is The Mind's Subjective Reality Real? zawiera dyskusję na temat psychowzroczności jako ukierunkowanej uważnej obecności i jej roli w leczeniu umysłów, w tym jej centralnej roli dla uzdrawiających relacji (między innymi na styku lekarzpacjent). Rozdział piąty Who Are We? odnosi się do pytania o naszą tożsamość ze względu na dwa sposoby przetwarzania informacji przez aparat poznawczy człowieka, czyli przetwarzania odgórnego i oddolnego (top-down, bottom-up). Rozdział szósty Where Is Mind? rozważa koncepcję tego, że umysł nie jest tylko czymś, co odbywa się we wnętrzu (na przykład w mózgu ani 
nawet $\mathrm{w}$ całym ciele, jak jest to przedstawiane w ucieleśnionych koncepcjach umysłu), lecz jest relacyjne, rozdystrybuowane, co z kolei nie pozwala na wytyczenie ostrych granic, takich jak mózg czy ciało. Rozdział siódmy A Why of Mind? podejmuje kwestie egzystencjalnego znaczenia umysłu, spekulując, że celem życia jest dążenie do integracji. Rozdział ósmy When Is Mind? jest refleksją nad tym, jak umysł funkcjonuje w czasie, czym jest czas dla umysłu oraz czy nie należałoby porzucić całkowicie koncepcji czasu ze względu na odkrycia współczesnej fizyki. Ostatnie dwa rozdziały A Continuum Connecting Consciousness, Cognition and Community? oraz Humankind: Can We Be Both? poddają ocenie możliwość istnienia swoistego kontinuum łączącego świadomość, poznanie, wspólnotę i jaźń rozumianą jako coś w formie mnogiej (posługując się neologizmem Siegela: $m e+$ we $=\mathrm{MWe}$ ) oraz warunki procesu integracji tożsamości.

Każdy z rozdziałów zakończony jest podrozdziałem zapraszającym do intymnej refleksji nad przedstawionymi ideami. Siegel w ten sposób pragnie utworzyć szczególną więź z czytelnikiem. Wynika to z jego silnego przekonania, że prawdziwa rozmowa o umyśle nie może zostać ograniczona do przedstawienia i zinterpretowania faktów. Wymaga ona szczególnego otwarcia się przed czytelnikiem przy jednoczesnym nastawionym na wspólne odkrywanie rozważaniu kolejnych idei. Wplatanie do dyskursu wątków autobiograficznych oraz wspominanie rozmów z przedstawicielami różnych nauk bardzo pomaga $\mathrm{w}$ zrozumieniu idei autora. Ponadto należy wspomnieć, że publikacja zawiera liczne zdjęcia mające wzbogacić poglądy autora o niewerbalne aspekty związane z doświadczaniem umysłu czy też sfery umysłu, które pomogą czytelnikowi w zrozumieniu jego podejścia do tej trudnej materii i pozwolą choć po części wspólnie połączyć się z pewnymi nastawieniami oferowanymi przez niego.

Niestety pomimo tak przystępnego przygotowania publikacji wiele kwestii może sprawić przeciętnemu czytelnikowi trudność ze względu na bardzo interdyscyplinarne podejście autora oraz rozwinięcie niektórych koncepcji obecnych w jego poprzednich publikacjach, a także nieraz spekulacyjny charakter przedstawianych idei. Dlatego Mind: A Journey to the Heart of Being Human polecałbym czytelnikom już zaznajomionym $\mathrm{z}$ jego wcześniejszymi pracami, przede wszystkim z The Developing Mind: How Relationships and the Brain Interact to Shape Who We Are (głównie ze względu na dokładne omówienie reguł działania systemów złożonych). Lektura Psychowzroczności (Media Rodzina, Poznań, 2011) także może okazać się przydatna w celu objęcia pełniejszego obrazu poglądów Siegela. Autor ma silną skłonność do 
tworzenia neologizmów i skrótów, które co prawda skutecznie organizują i ciekawie syntetyzują wiedzę (na przykład sieć wzbudzeń podstawowych, aktywności bazowej mózgu Default Mode Network jest przemianowana na OATS - Others And The Self, czyli sieć zajmującą się odnoszeniem się do siebie oraz relacji z innymi ludźmi), ale brak ich spisu może miejscami utrudniać lekturę. Ponadto należy wspomnieć, że rozdział $A$ Why of Mind?, poruszający kwestie egzystencjalne, robi wrażenie niedopracowanego. Integracja jest podawana nie tylko jako możliwy cel życia (co jest względnie dobrze wytłumaczone), ale także jako powód, dla którego wszyscy istniejemy. Pogląd ten jest przedstawiony bardzo zdawkowo i dobrym krokiem byłoby rozbudowanie tej kwestii w kolejnych publikacjach.

Zdecydowanie największą zaletą książki jest osobisty styl prezentowania kolejnych idei, który stoi u autora na bardzo wysokim poziomie. Siegel twierdzi, że od dawna chciał przyjąć taki styl prowadzenia dyskursu, został on jednak odrzucony w pierwszej wersji The Developing Mind i dopiero dziś mógł sobie pozwolić na ten typ narracji, który moim zdaniem sprawdza się bardzo dobrze przy tak szerokim omawianiu tego, czym jest umysł.

Przedstawione w książce pomysły są dość odważne. Przykładowo Siegel jest zwolennikiem porzucenia tradycyjnego pojmowania czasu na rzecz mówienia o procesach, które ulegają zmianie na krzywej rozkładu prawdopodobieństwa pomiędzy czystą potencjalnością a pewnością jakiegoś zdarzenia, w tym umysłowego. Następnie odnosi te procesy zmiany do wewnętrznego doświadczenia, jakie można mieć w trakcie praktyki uważności, gdzie bardzo głębokie stany medytacyjne (na przykład doświadczenie pustki w buddyzmie) porównuje do przebywania swoim stanem umysłu bardzo blisko zerowej szansy na pojawienie się jakiegoś bardziej konkretnego stanu umysłu (takiego jak na przykład wyobrażenie konkretnego przedmiotu, zdarzenia) a więc doświadczenie czystej potencjalności. Natomiast jest to z pewnością nowe, świeże spojrzenie na to, czym jest medytacja i czego się doświadcza oraz czego można doświadczyć w jej trakcie. Ten wstęp teoretyczny jest bardzo przydatny przed przystąpieniem do wypróbowania na samym sobie nowatorskiej metody medytacji Wheel of Awareness ${ }^{2}$, opracowanej przez Siegela. Polega ona na doświadczaniu swoimi zmysłami różnych typów rzeczy, które możemy sobie uświadomić, w uporządkowanej kolejności. Siegel dzieli zmysły na osiem rodzajów, doświadczanych w medytacji w następującym

${ }^{2}$ Kierowana medytacja i materiały dodatkowe są dostępne na stronie domowej autora: http://www.drdansiegel.com/resources/wheel_of_awareness/(dostęp: 5.03.2017). 
porządku: pięć zmysłów podstawowych (wzrok, słuch, smak, węch, dotyk), szósty zmysł odczuwania wnętrza własnego ciała, siódmy zmysł odczuwania swoich własnych aktywności mentalnych (doświadczania obrazów, myśli oraz uczuć), a także, moim zdaniem najciekawszy, zmysł bycia połączonym/w relacji z innymi ludźmi/istotami żywymi. Całość medytacji jest zakończona próbą doświadczania własnej świadomości (świadomości swojej świadomości). Przedstawiona rama teoretyczna oraz praktyka Wheel of Awareness powinna być intuicyjna dla osób zaznajomionych $\mathrm{z}$ naukami poznawczymi oraz praktykującymi mindfulness i ponadto może się okazać twórczym polem dla badaczy technik typu umysł-ciało, którzy chcieliby eksperymentalnie dogłębniej dociekać prawdziwości hipotez Siegela.

Mind: A Journey to the Heart of Being Human jest z pewnością interesującą pozycją dla osób zajmujących się badaniem umysłu, kwestiami zdrowia psychicznego, którym pozwoli zapoznać się z najnowszymi odkryciami, a także odważnymi rozważaniami w tej dziedzinie. Będzie ważną pozycją także dla tych, którzy praktykują medytację i chcieliby zrozumieć, czym jest i jak działa umysł - dzięki Siegelowi otrzymają niezwykle holistyczną i satysfakcjonującą odpowiedź na związane z tym kwestie.

Wojciech Sak

Uniwersytet Mikołaja Kopernika, Toruń, Polska wojciech.r.sak@gmail.com 